\title{
EFEKTIVITAS PEMBELAJARAN PJOK MENGGUNAKAN MEDIA AUDIO VISUAL SAAT PANDEMI COVID - 19 DI BANGKA BELITUNG
}

\author{
Muhammad E.M Simbolon ${ }^{1}$, Nerri Lestari ${ }^{2}$, Monica $^{3}$, Tungki Armanto ${ }^{4}$, Bayu Alfarras ${ }^{5}$ \\ Universitas Muhammadiyah Bangka Belitung ${ }^{1,2,3,4,5}$ \\ nerril16@gmail.com
}

\begin{abstract}
ABSTRAK
Tujuan dari penelitian ini adalah untuk mengetahui efektivitas pembelajaran penjas saat pandemi covid-19 menggunakan media audio visual pada satuan pendidikan sekolah dasar di Provinsi Kepulauan Bangka Belitung. Metode yang digunakan dalam penelitian ini adalah dekskriptif kuantitatif dengan metode survei menggunakan angket. Angket terdiri dari 15 butir pertanyaan yang bertujuan mengungkapkan efektivitas pembelajaran pjok menggunakan media audio visual saat pandemi covid-19 di Bangka Belitung. Responden penelitian ini sebanyak 514 orang, yang terdiri dari peserta didik sebanyak 343 orang, guru sebanyak 19 orang, dan orang tua sebanyak 152 orang. pembelajaran secara online dengan menggunakan media audio visual siswa mampu memahami materi pembelajaran. Disamping itu hasil belajar siswa juga mengalami peningkatan. Selama pandemi pembelajaran secara online salah satunya medio audio visual menjadi alternatif dalam menyampaikan materi pembelajaran, pernyataan ini didukung dengan data penelitian dimana penggunaan media audio visual sangat cocok digunakan selama pendemi covid-19. Melihat dari situasi saat ini dengan semakin merebaknya wabah pandemi satuan pendidikan perlu meningkatkan kualitas penggunaan media audio visual agar siswa lebih efektif dan termotifasi dalam belajar.
\end{abstract}

kata kunci: covid-19; audio visual; efektivitas; pjok; Bangka Belitung

\begin{abstract}
The purpose of this study was to determine the effectiveness of physical education learning during the Covid-19 pandemic using audio-visual media in elementary school education units in the Province of Bangka Belitung Islands. The method used in this research is descriptive quantitative with a survey method using a questionnaire. The questionnaire consisted of 15 questions aimed at revealing the effectiveness of learning corner using audiovisual media during the Covid-19 pandemic in Bangka Belitung. The respondents of this study were 514 people, consisting of 343 students, 19 teachers, and 152 parents. online learning using audio visual media students are able to understand the learning material. Besides that, student learning outcomes have also increased. During the online learning pandemic, one of which is audio-visual media as an alternative in delivering learning material, this statement is supported by research data where the use of audio-visual media is very suitable for use during the Covid-19 pandemic. Seeing the current situation with the increasing outbreak of a pandemic, education units need to improve the quality of the use of audio visual media so that students are more effective and motivated in learning.
\end{abstract}

Keywords: covid-19; audio visual; effectiveness; corner; Bangka Belitung

Dipublikasikan Oleh :

UPT Publikasi dan Pengelolaan Jurnal

Universitas Islam Kalimantan Muhammad Arsyad Al-Banjari Banjarmasin 


\section{PENDAHULUAN}

Pembelajaran merupakan hal yang penting dalam kehidupan manusia. Pembelajaran merupakan bentuk jamak dari kata belajar yang mempunyai kata dasar ajar. Ajar menurut KBBI adalah petunjuk yang diberikan kepada orang supaya diketahui (diturut), belajar merupakan suatu usaha untuk memperoleh kepandaian/ilmu. (Mansyur, 2020) Metode pembelajaran tidak bisa dipisahkan dari media pembelajaran karena memiliki hubungan yang saling berkaitan. Media yang bagus dan canggih tanpa didukung dengan metode guru yang baik dan kreatif akan menjadikan pembelajaran tidak maksimal. (Handarini \& Wulandari, 2020) pembelajaran daring merupakan pembelajaran yang dilakukan secara online dengan jarak jauh atau pembelajaran yang dilakukan peserta didik dimanapun dan kapanpun saat dibutuhkan. Sehingga dapat menghindari kerumunan yang dianggap sebagai salah satu cara untuk menerapkan social distancing.

(Rohmawati, 2015) Efektivitas pembelajaran adalah ukuran keberhasilan dari suatu proses interaksi antar siswa maupun antara siswa dengan guru dalam situasi edukatif untuk mencapai tujuan pembelajaran. Efektivitas pembelajaran dapat dilihat dari aktivitas siswa selama pembelajaran berlangsung, respon siswa terhadap pembelajaran dan penguasaan konsep siswa. Untuk mencapai suatu konsep pembela- jaran yang efektif dan efisien perlu adanya hubungan timbal balik antara siswa dan guru untuk mencapai suatu tujuan secara bersama. Efektivitas dalam belajar (penjas) merupakan usaha untuk mencapai tujuan dalam pembelajaran dimana indikator pencapaiannya adalah penguasaan seluruh materi dan berdaya guna dalam kehidupan sehari-hari.

Dalam pembelajaran sangatlah susah dipaham tanpa menggunkan media, oleh sebab itu pendidik harus cermat dalam memilih media untuk membantu dalam proses belajar mengajar. (Supriyono, 2018) Media sebagai salah satu komponen dalam sistem itu, mempunyai fungsi sebagai sarana komunikasi non-verbal. Sebagai salah satu komponen sistem, berarti media mutlak harus ada atau harus dimanfaatkan di dalam setiap pembelajaran. (Falahudin, 2014) Media merupakan salah satu komponen pembelajaran, Pemanfaatan media seharusnya merupakan bagian yang harus mendapat perhatian pembelajar dalam setiap kegiatan pembelajaran.

Dalam penelitian ini, secara spesifik membahas metode pembelajaran pendidikan jasmani secara online Pembelajaran pendidikan jasmani secara online dilaksanakan dengan menggunakan media audio visual, (Sumarsono \& Anisa, 2018) Siswa yang terlihat sangat memahami jika pembelajaran yang dilakukan di dampingi oleh media audio visual yang dapat diputar berkali-kali. Media audio visual mempunyai keunggulan dengan menempatkan dua indera bekerja secara bersamaan. (Herlina \& Suherman, 2020) Distance learning model untuk mata pelajaran PJOK dengan collaborative approach bersama orang tua siswa menjadi solusi dan potensi pembelajaran pada sekolah dan wilayah yang tidak bisa menerapkan pembelajaran online yang terkendala oleh jaringan internet, sarana dan prasarana pendukung serta minimnya penguasaan guru dan siswa terhadap keterampilan pembelajaran online. dimana guru memberikan materi berupa video dari youtube kepada siswa dan siswa diberikan tugas untuk mempraktekkan kembali gerakkan atau tindakan di dalam video youtube terebut. Tugas tersebut dikumpulkan kepada guru dalam bentuk video, artinya siswa diminta untuk membuat video dari hasil pengamatannya terhadap video yang diberikan oleh guru. Persoalan yang muncul ialah siswa tidak memahami dan menangkap isi materi melalui video youtube. Hal yang sama juga terjadi kepada orang tua siswa, sebagai pendamping belajar di rumah.

Kurangnya pemahaman dan penangkapan isi materi melalui media audio visual dapat disebabkan oleh sulitnya penjelasan yang diberikan oleh pemateri di dalam video dan kurang menariknya video yang diberikan sehingga dapat menurunkan motivasi siswa dalam mengikuti kegiatan pembelajaran melalui media audio visual. (Jayul \& Irwanto, 2020) Model pembelajaran daring dapat diaplikasikan dalam pendidikan jasmani dengan metode portal schoology, dan vlog. Dengan kata lain metode tersebut memiliki aplikasi video, yang dapat digunakan untuk mendemontrasikan gerakan-gerakan dalam ranah psikomotor (bersifat praktikum).

Oleh karenaitu, tujuan dari penelitian ini adalah untuk mengetahui efektivitas pembelajaran pjok menggunakan media audio visual di masa pandemi covid-19 di Bangka Belitung yang diharapkan dapat memberikan manfaat bagi perkembangan fisik dan gerak siswa.

\section{METODE}

Metode yang digunakan dalam penelitian ini adalah metode deskriptif kuantitatif dengan pendekatan atau tipe survei, Sedangkan populasi dalam penelitian ini adalah seluruh sekolah dasar (SD) yang ada di Provinsi Bangka Belitung. Sampel yang digunakan adalah siswa, orang tua, dan guru yang ada di Bangka Belitung.

Dipublikasikan Oleh : 
Tabel 1. Data Responden

\begin{tabular}{lccc}
\hline \multicolumn{1}{c}{ Domisili } & Jumlah & Laki-laki & Perempuan \\
\hline Keseluruhan Bangka & 514 & 22090 & 294 \\
& 223 & & 133 \\
Bangka Tengah & 81 & 18 & 63 \\
Bangka Barat & 103 & 60 & 43 \\
Bangka Selatan & 3 & 1 & 2 \\
Pangkalpinang & 104 & 51 & 53 \\
\hline
\end{tabular}

Berdasarkan data responden penelitian ini sebanyak 514 orang yang terdiri dari Kabupaten Bangka sebanyak 223 orang, yang terdiri dari siswa sebanyak 110 orang, orang tua sebanyak 105 orang, dan guru sebanyak 8 orang. Dari kabupaten Bangka Tengah sebanyak 81 orang yang terdiri dari siswa 59 orang, orang tua sebanyak 19 orang, dan guru sebanyak 3 orang. Dari Kota Pangkalpinang sebanyak 104 orang yang terdiri dari siswa sebanyak 89 orang, orang tua sebanyak 15 orang. Dari Kabupaten Bangka Barat sebanyak 103 orang yang terdiri dari siswa sebanyak 85 orang, orang tua sebanyak 10 orang, dan guru sebanyak 8

\section{Prosedur Penelitian}

orang. Dari bangka selatan sebanyak 3 orang yang terdiri dari orang tua sebanyak 3 orang.

Agar proses penelitian pada metode penelitian deskriptif kuantitati lebih terarah, sehingga dibuat desain, untuk desain penelitian yang diterapkan dalam penelitian ini yaitu menggunakan penelitian data angket. Dimana disetiap siswa/siswi, orang tua, dan guru PJOK mengisi setiap butir soal yang berada di dalam angket tersebut. Desain penelitiannya dapat dilihat sebagai berikut:

- Menyebarkan angket kepada siswa/siswi

- Menyebarkan angkket kepada orang tua murid

- Meneybarkan angket kepada guru pendidikan jasmani olahraga dan kesehatan

\section{Instrumen Penelitian}

Instrumen penelitian yang digunakan dalam penelitian ini berupa angket yang terdiri dari 15 butir pertanyaan yang bertujuan mengungkapkan dampak covid-19 pada pembelajaran pendidikan jasmani olahraga dan kesehatan sekolah dasar di Provinsi kepulauan Bangka Belitung. Angket yang digunakan berupa angket tertutup. Berikut 15 butir pertanyaan tersebut.

Tabel 2. Butir Pertanyaan Angket

\begin{tabular}{ll}
\hline No & Pertanyaan \\
\hline 1. & $\begin{array}{l}\text { Apakah Selama pandemi semolah menggunakan sistem } \\
\text { pembelajaran audio visual? }\end{array}$ \\
2. & $\begin{array}{l}\text { Apakah pembelajaran yang menggunakan audio visual selama pandemi ini membantu } \\
\text { memahami suatu pembelajaran? }\end{array}$ \\
3. & Apakah dengan pembelajaran audio visual siswa lebih aktif dan bersemangat dalam aktivitas \\
& belajar? \\
4. Apakah pembelajaran secara online lebih efektif dari pada tatap muka? \\
5. Apakah pembelajaran online sering dikendalai oleh jaringan? \\
6. Apakah selama pandemi guru mampu menyampaikan materi dengan baik? \\
7. Apakah dimasa pandemi ini siswa lebih susah untuk belajar? \\
8. Apakah dimasa pandemi ini siswa lebih senang barmain dari pada belajar? \\
9. Apakah selama pandemi ini pihak sekolah terjun langsung ke masingmasing siswa untuk \\
\end{tabular}


10. Apakah tugas yang diberikan selama pandemi ini, mampu menumbuhkah kreativitas siswa?

11. Apakah selama pandemi ini siswa menurun dalam hasil belajaar?

12. Apakah siswa memliki smartphone untuk belajar?

13. Apakah tugas yang diberikan sulit untuk diselesaikan?

14. Menurut anda apakah pembelajaran menggunakan median audio visual cocok digunakan di masa pandemi covid-19 sekarang?

15. Apakah pembelajaran menggunakan media audio visual selama pandemi siswa lebih percaya diri dari pada pembelajaran sebelum pandemi?

\section{HASIL DAN PEMBAHASAN}

Selama pandemi ini siswa sekolah dasar di Bangka Belitung yang menggunakan media audio visual. hasil penelitian kami untuk mengukur keefetifan media audio visual dapat disajikan pada tabel 3.

Tabel 3. Data Setiap Butir Angket

\begin{tabular}{|c|c|c|c|c|c|c|c|c|c|}
\hline \multirow[t]{2}{*}{ Data Angket } & \multicolumn{2}{|c|}{ Keseluruhan } & \multicolumn{3}{|c|}{ Guru } & \multicolumn{2}{|l|}{ Siswa } & \multicolumn{2}{|c|}{ Orang Tua } \\
\hline & $\sum$ & $\%$ & & $\sum \%$ & & $\sum$ & & $\Sigma$ & $\%$ \\
\hline \multirow[t]{2}{*}{ Butir 1} & Ya & 514 & 100 & 19 & 100 & 343 & 100 & 153 & 100 \\
\hline & Tidak & 0 & 0 & 0 & 0 & 0 & 0 & 0 & 0 \\
\hline Butir 2 & $\begin{array}{l}\text { Ya } \\
\text { Tidak }\end{array}$ & $\begin{array}{c}354 \\
160\end{array}$ & $\begin{array}{c}68.88 \\
31.12\end{array}$ & $\begin{array}{c}16 \\
3\end{array}$ & $\begin{array}{c}84.21 \\
15.79\end{array}$ & $\begin{array}{l}253 \\
90\end{array}$ & $\begin{array}{c}73.77 \\
26.23\end{array}$ & $\begin{array}{c}85 \\
67\end{array}$ & $\begin{array}{l}55.92 \\
44.08\end{array}$ \\
\hline \multirow{2}{*}{ Butir 3} & $\mathrm{Ya}$ & 230 & 44.75 & 12 & 63.16 & 154 & 44.90 & 64 & 42.10 \\
\hline & Tidak & 284 & 55.25 & 7 & 36.84 & 189 & 55.10 & 88 & 57.90 \\
\hline \multirow{2}{*}{ Butir 4} & $\mathrm{Ya}$ & 70 & 13.61 & 2 & 10.52 & 53 & 15.46 & 15 & 09.87 \\
\hline & Tidak & 444 & 86.39 & 17 & 89.48 & 290 & 84.54 & 137 & 90.13 \\
\hline \multirow[t]{2}{*}{ Butir 5} & $\mathrm{Ya}$ & 364 & 70.81 & 15 & 78.94 & 236 & 68.80 & 113 & 74.34 \\
\hline & Tidak & 150 & 29.19 & 4 & 21.06 & 107 & 31.20 & 39 & 25.66 \\
\hline \multirow{2}{*}{ Butir 6} & $\mathrm{Ya}$ & 324 & 63.03 & 15 & 78.94 & 231 & 67.34 & 78 & 51.31 \\
\hline & Tidak & 190 & 36.97 & 4 & 21.06 & 112 & 32.66 & 74 & 48.69 \\
\hline \multirow[t]{2}{*}{ Butir 7} & $\mathrm{Ya}$ & 395 & 76.84 & 14 & 73.69 & 256 & 74.63 & 125 & 82.23 \\
\hline & Tidak & 119 & 23.16 & 5 & 26.31 & 87 & 25.37 & 27 & 17.77 \\
\hline \multirow[t]{2}{*}{ Butir 8} & $\mathrm{Ya}$ & 397 & 77.23 & 15 & 78.94 & 250 & 72.89 & 132 & 86.84 \\
\hline & Tidak & 117 & 22.77 & 4 & 21.06 & 93 & 27.11 & 20 & 13.16 \\
\hline \multirow[t]{2}{*}{ Butir 9} & $\mathrm{Ya}$ & 170 & 33.08 & 10 & 52.63 & 110 & 32.07 & 50 & 32.90 \\
\hline & Tidak & 344 & 66.92 & 9 & 47.37 & 233 & 67.93 & 102 & 67.10 \\
\hline \multirow[t]{2}{*}{ Butir 10} & $\mathrm{Ya}$ & 186 & 36.19 & 10 & 57.63 & 124 & 36.16 & 52 & 34.21 \\
\hline & Tidak & 328 & 63.81 & 9 & 47.37 & 219 & 63.84 & 100 & 65.79 \\
\hline \multirow[t]{2}{*}{ Butir 11} & $\mathrm{Ya}$ & 391 & 76.08 & 17 & 89.48 & 252 & 73.47 & 122 & 80.27 \\
\hline & Tidak & 123 & 23.92 & 2 & 10.52 & 91 & 26.53 & 30 & 19.73 \\
\hline \multirow[t]{2}{*}{ Butir 12} & $\mathrm{Ya}$ & 288 & 56.03 & 4 & 21.06 & 211 & 61.51 & 73 & 48.02 \\
\hline & Tidak & 226 & 43.97 & 15 & 78.94 & 132 & 38.49 & 79 & 51.98 \\
\hline
\end{tabular}

Dipublikasikan Oleh :

UPT Publikasi dan Pengelolaan Jurnal

Universitas Islam Kalimantan Muhammad Arsyad Al-Banjari Banjarmasin 


\begin{tabular}{llcccccccc} 
Butir 13 & Ya & 258 & 50.20 & 4 & 21.06 & 176 & 51.31 & 78 & 51.31 \\
& Tidak & 256 & 49.80 & 15 & 78.94 & 167 & 48.68 & 74 & 48.69 \\
Butir 14 & Ya & 412 & 80.16 & 18 & 94.73 & 267 & 77.84 & 127 & 83.56 \\
& Tidak & 102 & 19.84 & 1 & 05.27 & 76 & 22.16 & 25 & 16.44 \\
\multirow{3}{*}{ Butir 15 } & Ya & 149 & 28.99 & 3 & 15.79 & 90 & 26.23 & 56 & 36.84 \\
& Tidak & 365 & 71.01 & 16 & 84.21 & 253 & 73.77 & 96 & 63.16 \\
\hline
\end{tabular}

Data penelitian menunjukkan sebesar $68,88 \%$ pembelajaran menggunakan media audio visual selama pandemi dapat membantu siswa memahami materi pelajaran, sedangkan yang tidak setuju sebesar $31,12 \%$. Berdasarkan penelitian (Hadi, 2017) temuan dari kelebihan video yang diantaranya bersifat menyenangkan bagi siswa, mampu memberikan sajikan informasi yang konkret, dan mampu menghadirkan pengalaman belajar yang tidak mungkin didapatkan siswa di luar lingkungan sekolah, seperti sejarah kemerdekaan misalnya. Ketiga kelebihan tersebut menjadikan video dinilai efektif untuk meningkatkan kemampuan siswa dalam memahami konsep, meningkatkan motivasi belajar siswa serta mampu meningkatkan hasil belajar siswa. Selain itu, media video juga dinilai efektif digunakan untuk jenjang siswa sekolah dasar karena ketiga kelebihan tersebut dapat memenuhi kebutuhan belajar siswa sekolah dasar yang berada pada fase operasional konkret. Berdasarkan hasil penelitian (Louk \& Sukoco, 2016) bahwa media audio visual dalam pembelajaran keterampilan motorik kasar anak tunagrahita ringan kelas bawah ini sangat baik dan efektif. Oleh karena itu, media pembalajaran yang dikembangkan ini layak untuk digunakan dan diterapkan dalam pembelajaran pendidikan jasmani untuk anak tunagrahita ringan.

Berdasarkan data penelitian penggunaan media audio visual mata pelajaran PJOK diperoleh hasil sebesar 44,75\% siswa lebih aktif dalam aktifitas belajar, sedangkan yang tidak setuju sebesar 55,25\%. (Ratminingsih, 2016) menyatakan membuktikan bahwa semua siswa (100\%) menunjukkan persepsi positif terhadap pemanfaatan media audio berbasis lagu. Mereka menjadi lebih termotivasi untuk belajar karena melalui lagu pembelajaran menjadi menyenangkan, menarik, dan materi lebih mudah dipahami. Menurut (Novita et al., 2019) bahwa terdapat pengaruh yang positif dan signifikan antara penggunaan media pembelajaran audio visual video terhadap hasil belajar Subtema 1 Keberagaman Budaya Bangsaku pada kelas IV A dan IV B Sekolah Dasar Negeri Babakan 01 Semester 1 Tahun Ajaran 2019/2020. Hasil penelitian (Gading \& Kharisma, 2017) Perbedaan hasil belajar antara siswa yang diberi perlakuan dengan model pembelajaran Make a Match berbantuan media audio visual dan siswa yang tidak diberi perlakuan dengan model pembelajaran Make a Match berbantuan media audio visual disebabkan adanya perbedaan perlakuan pada proses pembelajaran. Hal ini terjadi karena model kooperatif tipe make a match berbantuan media audio visual merupakan salah satu model pembelajaran yang dapat memberikan kesempatan kepada siswa belajar dengan kreatif dan inovatif. Dengan dukungan media audio visual (video) lengkap rasanya pembelajaran yang menyenangkan didapat siswa, berbagai hal positif didapatkan siswa dari pembelajaran menggunakan model kooperatif tipe make a match berbantuan audio visual salah satunya adalah hasil belajar yang bagus. Menurut hasil penelitian (Perwitasari \& Abidin, 2014) mengungkapkan penerapan model Time Token Arends dengan media Audio Visual dapat meningkatkan kualitas pembelajaran PKn kelas V SDN Tambakaji 03 Semarang.

Data penelitian terkait perbandingan efektifitas pembelajaran secara online dengan tatap muka menunjukkan hasil sebesar $13,61 \%$ pembelajaran secara online lebih efektif selama pandemi, sedangkan yang tidak setuju sebesar 86,39\%. Berdasarkan hasil penelitian dari (Hamdani \& Priatna, 2020) menyatakan bahwa tingkat tingkat efektifitas pembelajaran sekitar 66,97 \%, hal ini perlu ditingkatkan kembali agar pembelajaran lebih efektif guna peningkatan kualitas pembelajaran dan hasil belajar siswa.

Berdasarkan data penelitian yang telah dilakukan sebesar $70,81 \%$ responden mengatakan bahwa jaringan merupakan salah satu kendala dalam pembelajaran secara online, sedangkan yang tidak setuju sebesar 29,19\%. Berdasarkan hasil penelitian (Mastura \& Santaria, 2020) mengatakan bahwa adapun kendala yang paling mendasar yaitu fasilitas yang kurang memadai karena biasanya guru maupun peserta didik melakukan proses pembelajaran dengan fasilitas yang cukup memadai namun dihadapkan dengan fasilitas yang hanya bergantung pada internet.

Data penelitian yang diperoleh menunjukkan sebesar 63,35\% guru mampu menyampaikan materi pembelajaran secara online dengan baik, sedangkan yang tidak setuju sebesar $36,79 \%$. Menurut hasil penelitian (Utami, 2013) menunjukan bahwa aktivitas guru saat pembelajaran dengan menggunakan media audio visual

Dipublikasikan Oleh : 
berjalan dengan baik dan mengalami peningkatan sebesar 10,10\%. Begitu pula aktivitas siswa mengalami peningkatan sebesar 6,56\%. Dalam proses pembelajaran daring yang dilakukan siswa tidak lepas dari pengawasan orang tua dan guru. Berdasarkan hasil penelitian (Astini, 2020) mengungkapkan bahwa untuk mendapatkan proses pembelajaran yang efektif dan menyenangkan diperlukan kerjasama guru dan orang tua dengan proses pembelajaran yang berpariatif.

Berdasarkan data penelitian menunjukkan bahwa sebesar 76,84\% siswa lebih sulit unutk belajar di masa pendemi covid-19, sedangkan yang tidak setuju sebesar $32,16 \%$.

Menurut (Hayati et al., 2017) Terdapat hubungan yang signifikan antara penggunaan media pembelajaran audio visual dengan minat peserta didik pada pembelajaran.

Diperoleh data dari hasil pelitian bahwa sebesar 77,23\% siswa lebih senang untuk bermain dari pada belajar selama masa pandemi, sedangkan yang tidak setuju sebesar 22,77\%. Dari data penelitian sebesar 33,08\% selama masa pandemi guru mendatangi rumah siswa untuk memberikan tugas atau materi pembelajaran sedangkan yang tidak mendatangi rumah sebesar $66,92 \%$.

Berdasarkan data penelitian diperoleh hasil sebesar 36,19\% tugas yang diberikan selama pandemi dapat menumbuhkan kreatifitas siswa, sedangkan yang tidak setuju sebesar 63,81\%. penelitian yang dilakukan oleh (Insyasiska et al., 2015) menunjukkan bahwa berdasarkan uji lanjut LSD pembelajaran project based learning dapat mempengaruhi motivasi belajar siswa lebih tinggi 14\%, kreativitas siswa meningkat 31,1\%, kemampuan berpikir kritis meningkat 34\% dan Melalui pembelajaran proyek yang bersifat kontekstual, kemampuan kognitif siswa juga meningkat 28,9\% dari pada pembelajaran yang diberikan tanpa melalui proyek. Berdasarkan hasil penelitian (Dewi et al., 2014) mengatakan bahwa terdapat perbedaan hasil belajar IPS yang signifikan antara siswa yang dibelajarkan dengan model pembelajaran Circuit Learning berbantuan media audio visualdan siswa yang dibelajarkan dengan model pembelajaran konvensional di kelas V semester 1 SDNegeri1 Pejeng Gianyar tahun pelajaran 2013/2014.

Data penelitian menunjukkan sebesar $76,08 \%$ siswa mengalami penurunan dalam belajar selama pandemi, sedangkan yang tidak setuju sebesar 32,92\%. Penelitian yang dilakukan oleh (sigit vebrianto susilo, 2020) menyatakan bahwa media lebih efektif dalam meningkatkan hasil belajar siswa jika dibandingkan tanpa menggunkan media audio visual. Media dapat mengaktifkan seluruh siswa selama proses pembelajaran dan memberikan kesempatan untuk bekerjasama antar siswa yang mempunyai kemampuan heterogen. Hasil penelitian (Hastuti \& Budianti, 2014) mengungkapkan bahwa terdapat perbedaan hasil belajar antara siswa yang menggunakan media audio visual dengan siswa yang menggunakan media gambar pada pembelajaran IPA. Berdasarkan hasil penelitian menyatakan bahwa media audio visual berpengaruh positif terhadap hasil belajar IPA siswa kelas II Sekolah Dasar.

Menurut data penelitian menunjukkan hasil sebesar 56,03\% siswa memiliki handphone pribadi untuk belajar, sedangkan yang memiliki handphone sebesar 43,97\%. Penelitian (Handarini \& Wulandari, 2020) mengatakan bahwa dalam pembelajaran daring membutuhkan sarana dan prasarana yang memadai, seperti laptop, komputer, smartphone dan jaringan internet. Hal itulah yang menjadi salah satu tantangan untuk melakukan pembelajaran daring. Namun seorang siswa meskipun tidak semua memiliki laptop atau komputer, sebagian besar mereka memiliki smartphone. Dari hasil penelitian menunjukkan data sebesar 50,20\% siswa sulit untuk menyelesaikan tugas yang diberikan, sedangkan yang tidak setuju sebesar $49,80 \%$.

Berdasarkan hasil penelitian di peroleh data sebesar 80,16\% pembelajaran PJOK menggunakan media audio visual cocok untuk digunakan selama masa pandemi, sedangkan yang tidak setuju sebesar $19,84 \%$. Menurut hasil penelitian (Tarida, 2020) dalam penelitiannya menunjukan Pemanfaatan Google Classroom yang dilengkapi dengan Video Pembalajaran berbasis Problem Solving dapat menjadi solusi alternatif pembelajaran daring di

Era Pandemi Covid-19. Hal ini karena dosen dan taruna/i tidak perlu bertatap muka langsung.

Taruna/i dapat mengakses Google Classroom dan video pembelajaran dimanapun dengan bantuan perangkat PC/handphone dan jaringan internet, sehingga meminimalisir angka kenaikan penderita Covid-19. Menurut penelitian (Virgiana \& Wasitohadi, 2015) menunjukan bahwa terdapat perbedaan tingkat efektivitas antara model problem based learning berbantu media audio visual dengan model pembelajaran think pair share berbantu media visual terhadap hasil belajar IPA siswa kelas 5 SDN 1 Gadu Kecamatan Sambong Kabupaten Blora semester 2 tahun 2014/2015. Terbukti hal ini ditunjukkan oleh hasil uji t-test sebesar 3,603>1,999 dan signifikansi sebesar $0,001<0,05$. Perbedaan rata-rata kelas eksperimen > rata-rata kelas kontrol yaitu 87,0588 > 80,2000 .

\section{Dipublikasikan Oleh :}


Data penelitian menunjukkan hasil sebesar $28,99 \%$ pembelajaran menggunakan media audio visual dapat menumbuhkan rasa percaya diri siswa, sedangkan yang tidak setuju sebesar $71,01 \%$.

\section{PENUTUP}

Berdasarkan hasil penelitian dan interpretasi data tentang "Efektivitas Pembelajaran Pjok Menggunakan Media Audio Visual Saat Pandemi Covid - 19 Di Bangka Belitung" menunjukkkan hasil yang baik, artinya pembelajaran secara online dengan menggunakan media audio visual siswa mampu memahami materi pembelajaran. Disamping itu hasil belajar siswa juga mengalami peningkatan. Selama pandemi pembelajaran secara online salah satunya medio audio visual menjadi alternatif dalam menyampaikan materi pembelajaran, pernyataan ini didukung dengan data penelitian dimana penggunaan media audio visual sangat cocok digunakan selama pendemi covid-19. Melihat dari situasi saat ini dengan semakin merebaknya wabah pandemi satuan pendidikan perlu meningkatkan kualitas penggunaan media audio visual agar siswa lebih efektif dan termotifasi dalam belajar.

\section{REFERENSI}

Astini, N. K. S. (2020). Pemamfaatan Teknologi Informasi Dalam Pembelajaran Tingkat Sekolah Dasar Pada Masa Pandemi Covid-19. Jurnal Lampuhyang Lembaga Penjaminan Mutu STKIP Agama Hindu Amlapura, 11(2), 13-25.

Dewi, D. A. P., Wiyasa, I. K. N., \& Ganing, N. N. (2014). Pengaruh Model Pembelajaran Circuit Learning Berbantuan Media Audio Visual Terhadap Hasil Belajar IPS Siswa SDN 1 Pajeng Tahun Pelajaran 2013/2014. Jurnal Mimbar PGSD Universitas Pendidikan Ganesha, 2(1), 9-10.

Falahudin, I. (2014). Pemanfaatan Media dalam Pembelajaran. Jurnal Lingkar Widyaiswara, 1(4), 104-117.

Gading, I. K., \& Kharisma, K. D. (2017). Pengaruh Model Pembelajaran Kooperatif Tipe Make A Match Berbantuan Media Audio Visual Terhadap Hasil Belajar IPS Sekolah Dasar. International Journal Of Elementary Education, 1(2), 153-160.

Hadi, S. (2017). Efektivitas Penggunaan Video Sebagai Media. Jurnal Transformasi Pendidikan Abad 21, 1(15), 96-102.

Hamdani, A. R., \& Priatna, A. (2020). Efektifitas Implementasi Pembelajaran Daring (Full Online) Dimasa Pandemi Covid-19 Pada Jenjang Sekolah Dasar Di Kabupaten Subang. Jurnal Ilmiah PGSD STKIP Subang, 6(1), 1-9.

Handarini, O. I., \& Wulandari, S. S. (2020). Pembelajaran Daring Sebagai Upaya Study From Home ( SFH ) Selama Pandemi Covid 19. Jurnal Pendidikan Administrasi Perkantoran, 8(1), 496-503.

Hastuti, A., \& Budianti, Y. (2014). Pengaruh Penggunaan Media Audio Visual Terhadap Hasil Belajara Siswa Pada Mata Pelajaran IPA Kelas 2 SDN Bantargerbang 2 Kota Bekasi. Jurnal Pedagogik, II (2), 33-38.

Hayati, N., Ahmad, M. Y., \& Harianto, F. (2017). Hubungan Penggunaan Media Pembelajaran Audio Visual dengan Minat Peserta Didik pada Pembelajaran Pendidikan Agama Islam di SMAN 1 Bangkinang Kota. Jurnal Al-Hikmah, 14(2).

Herlina, \& Suherman, M. (2020). Potensi Pembelajaran Pendidikan Jasmani Olahraga dan Kesehatan (PJOK) di Tengah Pandemi Corona Virus Disease di Sekolah Dasar. Tudulako Journal Sport Sciences and Physical Education, 8(1), 5-6.

Dipublikasikan Oleh : 
Insyasiska, D., Zubaidah, S., Susilo, H., Biologi, P., \& Malang, U. N. (2015). Pengaruh Project Based Learning Terhadap Motivasi Belajar, Kreativitas, Kemampuan Berfikir Kritis, dan Kemampuan Kognitif Siswa Pada Pembelajaran Biologi. Jurnal Pendidikan Biologi, 7(1), 9-21.

Jayul, A., \& Irwanto, E. (2020). Model Pembelajaran Daring Sebagai Alternatif Proses Kegiatan Belajar Pendidikan Jasmani di Tengah Pandemi Covid-19. Jurnal Pendidikan Kesehatan Rekreasi, 6(2), 190-199. https://doi.org/10.5281/zenodo.3892262

Louk, M. J. H., \& Sukoco, P. (2016). Pengembangan Media Audio Visual Dalam Pembelajaran Keterampilan Motorik Kasar Pada Anak Tunagrahita Ringan. Jurnal Keolahragaan, 4(1), 24-33.

Mansyur, A. R. (2020). Dampak COVID-19 Terhadap Dinamika Pembelajaran Di Indonesia. Education and Learning Journal, 1(2), 113-123.

Mastura, \& Santaria, R. (2020). Dampak Pandemi Covid-19 terhadap Proses Pengajaran bagi Guru dan Siswa Pendahuluan. Jurnal Studi Guru Dan Pembelajaran, 3(2), 289-295. https://doi.org/https://doi.org/10.30605/jsgp.3.2.2020.293

Novita, L., Sukmanasa, E., \& Pratama, M. Y. (2019). Penggunaan Media Pembelajaran Video terhadap Hasil Belajar Siswa SD. Indonesia Journal Of Primary Education, 3(2), 64-72.

Perwitasari, A., \& Abidin, Z. (2014). Peningkatan Kualitas Pembelajaran pkn Melalui Model Time Token Arends Dengan Media Audio Visual. Jurnal Unnes, 3(1), 31-37.

Ratminingsih. (2016). Efektivitas media audio pembelajaran bahasa inggris berbasis lagu kreasi di kelas lima sekolah dasar. Jurnal Pendidikan Indonesia, 5(1), 27-38.

Rohmawati, A. (2015). Efektivitas Pembelajaran. Jurnal Pendidikan Usia Dini, 9(1), 17. sigit vebrianto susilo. (2020). Jurnal Cakrawala Pendas Penggunaan media pembelajaran berbasis audio visual untuk meningkatkan hasil belajar bahasa indonesia di sekolah dasar. Jurnal Cakrawala Pendas, 6(2), 108-115. https://doi.org/http://dx.doi.org/10.31949/jcp.v6i1.2100

Sumarsono, A., \& Anisa. (2018). Media Audio Visual Sebagai Solusi Efektif Pembelajaran Teknik Gerak. Jurnal Pendidikan Jasmani Dan Olahraga, 3(1).

Supriyono. (2018). Pentingnya Media Pembelajaran Untuk Meningkatkan Minat Belajar Siswa SD. Jurnal Pendidikan Dasar, 2(1), 43-48.

Tarida, L. (2020). Pemanfaatan Google Classroom dan Video Pembelajaran berbasis Problem Solving sebagai Solusi Kegiatan Belajar Mengajar di Era Pandemi Covid-19. Jurnal Saintara, 5(1).

Utami, K. (2013). Penggunaan Media Audio Visual Untuk Meningkatkan Pemahaman Konsep Siswa di Sekolah Dasar. Jurnal PGSD FIB Universitas Negeri Surabaya, 1(9), 126.

Virgiana, A., \& Wasitohadi. (2015). Efektivitas model problem based learning bantuan media audio visual ditinjau dari hasil belajar ipa siswa kelas 5 SDN 1 Gadu Sambong-Blora Semester 2 Tahun 2014/2015. Jurnal Scholaria, 6(2), 100-118.

Dipublikasikan Oleh : 